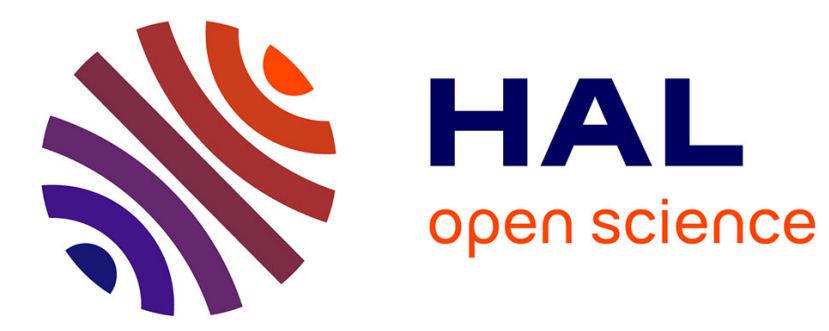

\title{
Impact of torrefaction on syngas production from wood
}

Carole Couhert, Sylvain Salvador, Jean-Michel Commandre

\section{To cite this version:}

Carole Couhert, Sylvain Salvador, Jean-Michel Commandre. Impact of torrefaction on syngas production from wood. Fuel, 2009, 88 (11), p.2286-2290. 10.1016/j.fuel.2009.05.003 . hal-01846922

\section{HAL Id: hal-01846922 \\ https://hal.science/hal-01846922}

Submitted on 6 Nov 2018

HAL is a multi-disciplinary open access archive for the deposit and dissemination of scientific research documents, whether they are published or not. The documents may come from teaching and research institutions in France or abroad, or from public or private research centers.
L'archive ouverte pluridisciplinaire HAL, est destinée au dépôt et à la diffusion de documents scientifiques de niveau recherche, publiés ou non, émanant des établissements d'enseignement et de recherche français ou étrangers, des laboratoires publics ou privés. 


\title{
Impact of torrefaction on syngas production from wood
}

\author{
C. Couhert ${ }^{\mathrm{a}, *}$, S. Salvador ${ }^{\mathrm{a}}$, J-M. Commandré ${ }^{\mathrm{b}}$ \\ a Ecole des Mines d'Albi - Carmaux, Centre RAPSODEE, UMR 2392-CNRS, Campus Jarlard, route de Teillet 81013, Albi CT Cedex 09, France \\ ${ }^{\mathrm{b}}$ CIRAD, UPR 42 Biomasse Energie, TA 10/16, 73, Avenue J.-F. Breton, 34398 Montpellier Cedex 5, France
}

\section{A B S T R A C T}

Torrefaction is a way to treat biomass before transportation or thermochemical conversion. It can be used to increase the energy content of wood or to facilitate grinding. The purpose of this paper was to quantify the impact of such a treatment on the behaviour of wood during gasification by steam at high temperature to produce syngas. The aspects of both gas yields and reaction kinetics were considered.

Beechwood was submitted both to light torrefaction and severe torrefaction, using a specially designed crossed fixed bed reactor. The initial wood and the torrefied woods were first characterised, then gasified in a new laboratory high-temperature entrained flow reactor (HT-EFR) at $1400^{\circ} \mathrm{C}$ for $2 \mathrm{~s}$ in an atmosphere containing $20 \mathrm{vol} \%$ steam in $\mathrm{N}_{2}$. The syngas produced was then analysed. The experiments were modelled using a thermo-dynamical equilibrium approach.

It was confirmed that torrefaction decreased the $\mathrm{O} / \mathrm{C}$ ratio. The quantity of syngas produced increased with the severity of the torrefaction. The equilibrium approach describes the results satisfactorily.

Gasification experiments carried out at a lower temperature $-1200^{\circ} \mathrm{C}$ - indicated that the chars from torrefied woods are less reactive towards steam than the char from wood.

\section{Introduction}

Thermo-chemical conversion of biomass is a means to produce energy and to reduce greenhouse gases. Rapid gasification of biomass at high temperature is one of the most promising technologies for the production of syngas. It can be achieved in several seconds in an entrained flow reactor. At high temperature $\left(1400^{\circ} \mathrm{C}\right)$, it is possible to obtain a syngas $\left(\mathrm{CO}, \mathrm{H}_{2}\right.$ and $\left.\mathrm{CO}_{2}\right)$ containing very small amounts of residual hydrocarbons and solid carbon (char). Heat and mass transfers are very effective in this kind of reactor, but the biomass must be dried and ground to particles measuring several hundreds of micrometers prior to injection. These preliminary steps, especially grinding, consume large amounts of energy and represent obstacles that need to be overcome in order to expand the use of biomass in thermochemical processes.

Torrefaction is a technology which allows moisture and low weight organic volatile components of biomass to be removed, producing a hydrophobic solid product with an increased energy density (on a mass basis) and greatly increased grindability [15]. Electricity requirements for size reduction of torrefied wood are $50-85 \%$ smaller in comparison with fresh wood [6,7].

To reduce solid mechanical properties, torrefaction is generally achieved in the temperature range of $220-300^{\circ} \mathrm{C}$, under an inert atmosphere. It forms three phases: a solid product of a dark colour,

\footnotetext{
* Corresponding author.

E-mail address: couhert@enstimac.fr (C. Couhert).
}

an acidic aqueous phase and permanent gases such as $\mathrm{CO}$ and $\mathrm{CO}_{2}$ $[2,8]$, typically $20 \%$ of $\mathrm{CO}$ and $80 \%$ of $\mathrm{CO}_{2}$ [9].

The kinetics of torrefaction reactions in the temperature range of $230-300{ }^{\circ} \mathrm{C}$ can be described accurately by a two-step mechanism. The first step is representative of hemicellulose decomposition, while the second step represents cellulose decomposition [10]. At temperatures above $300-320^{\circ} \mathrm{C}$, fast thermal cracking of cellulose may cause tar formation, so operation below $300^{\circ} \mathrm{C}$ is recommended.

Despite torrefaction is an energy consuming treatment, several works can be found on the advantages - in terms of the energy efficiency of a process - of torrefaction as a pre-treatment prior to gasification [9]. The concept of torrefaction - aided gasification is similar to two-stage pyrolysis-gasification but the advantage is that the heat requirements for torrefaction are smaller than those for pyrolysis at higher temperatures [9].

Some studies on torrefied wood reactivity have been realised under air in TGA or thanks to a burner [2,3]. However, studies carried out on gasification concern only raw biomass $[11,12]$. To our knowledge, no works can be found on the impact of torrefaction on the behaviour of wood during gasification by steam at high temperature in an entrained flow reactor, neither in terms of syngas quantities and composition, nor in terms of solid gasification kinetics.

In this paper, gas yields and reaction kinetics obtained during gasification of torrefied woods were studied. Beechwood was submitted to light torrefaction $\left(240^{\circ} \mathrm{C}\right)$ and severe torrefaction 
$\left(260^{\circ} \mathrm{C}\right)$, using a specially designed crossed fixed bed reactor. After characterisation, initial wood and torrefied woods were gasified in a new high-temperature entrained flow reactor at $1400{ }^{\circ} \mathrm{C}$ and $1200{ }^{\circ} \mathrm{C}$ for $2 \mathrm{~s}$ in an atmosphere containing 20 vol\% steam in $\mathrm{N}_{2}$. The syngas produced was analysed. The experiments conducted at $1400^{\circ} \mathrm{C}$ were modelled using a thermodynamical approach. Experiments carried out at $1200^{\circ} \mathrm{C}$ gave information on chemical reaction kinetics.

\section{Experimental}

\subsection{Characterisation of beechwood}

Beechwood was supplied by Lignex, France, as 50-500 $\mu \mathrm{m}$ particles. They were stored in plastic bags in a dark place at the temperature of the laboratory. The $80-200 \mu \mathrm{m}$ fraction was selected by sieving prior to any analysis or experiment. The ultimate analysis of the selected particles was compared to that of the supplied sample and did not deviate by more than $0.5 \%$, attesting to a non-selective sampling.

The wood contained 10\% moisture. As indicated by ultimate analysis performed on the dry wood, and reported in Table 1, the wood contained $50.3 \%$ of $\mathrm{C}, 5.3 \%$ of $\mathrm{H}$ and $44.4 \%$ of $\mathrm{O}$ on a dry ash free basis (daf). Proximate analysis performed on dry wood indicated a quantity of volatile matter of $84.2 \%$ and $0.3 \%$ of ash, resulting in a fixed carbon amount of $15.5 \%$.

\subsection{Torrefaction reactor and operating conditions}

Wood particle torrefaction was carried out in a specially designed reactor enabling accurate control of the temperature inside the sample body and rapid removal of the product gas. As illustrated in Fig. 1, the reactor consisted of a $60 \mathrm{~mm}$ i.d. quartz tube in which $25 \mathrm{~g}$ of wood particles were deposited on a ceramic wood layer. The reactor was surrounded by a $2 \mathrm{~kW}$ electrical furnace. The inert atmosphere gas, $\mathrm{N}_{2}$, was fed from the bottom at a flowrate of $0.31 \mathrm{~min}^{-1}$ at STP, heated along the lower part of the reactor and crossing the sample bed. It was expected that this method would ensure a good thermal contact between gas and all particles, while taking the gas products of torrefaction away from the bed (at a Darcy velocity of $0.0034 \mathrm{~m} \mathrm{~s}^{-1}$ at $250^{\circ} \mathrm{C}$ ). At the top of the reactor, a ceramic wool swab prevented air from entering the reactor by natural convection effects. The gas temperature upstream of the sample was recorded.

Particles were deposited in the cold reactor. The inert gas flow was started and maintained. The reactor was then heated to the stage temperature, following a ramp at $10 \mathrm{~K} \mathrm{~min}^{-1}$. The temperature was maintained for $1 \mathrm{~h}$ alternatively at $240^{\circ} \mathrm{C}$ and $260^{\circ} \mathrm{C}$; natural cooling was then allowed to occur.

When collecting the torrefied samples from the reactor, a uniform colour was observed inside the sample body - which was darker than the initial wood - attesting to a uniform torrefaction progression. Indeed, other tests performed even on much smaller samples but without inert gas circulation resulted in clearly nonuniform conversion inside the sample body.

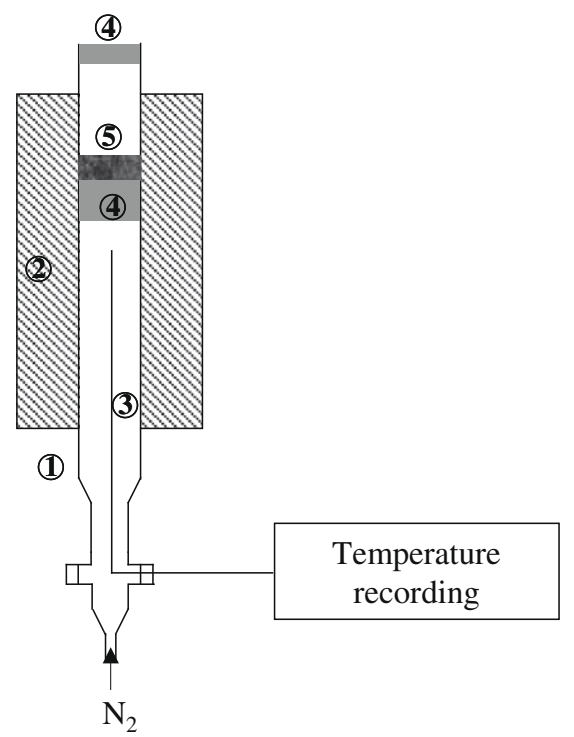

1: reactor; 2: furnace; 3: thermocouple; 4: ceramic wool; 5: wood

Fig. 1. Torrefaction reactor.

\subsection{Gasification reactor and operating conditions}

The gasification of wood and torrefied woods was carried out in a High Temperature Entrained Flow Reactor (HT-EFR) specifically set up to achieve high heating-rate wood gasification. This HTEFR is electrically heated by a $18 \mathrm{~kW}$ three-zone electrical furnace, and is able to reach $1600^{\circ} \mathrm{C}$ in a $1 \mathrm{~m}$ long isothermal reaction zone. As illustrated in Fig. 2, wood particles were fed at a very constant mass flowrate of $0.5 \mathrm{~g} \mathrm{~min}^{-1}$ thanks to a new in-house-designed gravimetric feeding system, and continuously injected in the reactor through a hot-oil cooled feeding probe. They were uniformly dispersed on the section of a $75 \mathrm{~mm}$ i.d. alumina reactor swept by $22.41 \mathrm{~min}^{-1}$ at STP of an atmosphere gas containing $20 \mathrm{vol} \%$ of steam in $\mathrm{N}_{2}$. With such solid and gas flow rates, steam is present in largely stoichiometric conditions. Atmosphere gas was generated by feeding the controlled flows of water and nitrogen in a $2 \mathrm{~kW}$ electrical steam generator. This atmosphere gas was then preheated using a $2.5 \mathrm{~kW}$ electrical battery of heating elements before reaching the $1 \mathrm{~m}$ long isothermal reaction zone, itself heated by the electrical furnace. Gasification took place in the reactor during a controlled residence time (typically several seconds). At $1760 \mathrm{~mm}$ downstream of the injection point, gases and particles were sampled by a hot-oil cooled probe, and separated using a settling box and a filter, both heated to avoid water condensation. The water was first condensed in a heat exchanger, and non-condensable gases were forwarded to:

- a non dispersive IR analyser and FTIR analyser to quantify CO, $\mathrm{CO}_{2}, \mathrm{CH}_{4}, \mathrm{C}_{2} \mathrm{H}_{2}$ and $\mathrm{C}_{2} \mathrm{H}_{4}$,

- a TCD to quantify $\mathrm{H}_{2}$.

Table 1

Ultimate analysis and proximate analysis of wood and torrefied woods.

\begin{tabular}{|c|c|c|c|c|c|c|c|c|}
\hline & \multicolumn{5}{|c|}{ Ultimate analysis (daf mass \%) } & \multicolumn{3}{|c|}{ Proximate analysis (dry mass \%) } \\
\hline & $\mathrm{C}$ & $\mathrm{H}$ & $\mathrm{N}$ & $\mathrm{S}$ & 0 & Ash & Volatile matters & Fixed carbon \\
\hline Beechwood & 50.3 & 5.3 & 0 & 0 & 44.4 & 0.3 & 84.2 & 15.5 \\
\hline Torrefied beechwood $240^{\circ} \mathrm{C}$ & 51.7 & 5.4 & 0 & 0 & 42.9 & 0.35 & 80.6 & 19.2 \\
\hline Torrefied beechwood $260^{\circ} \mathrm{C}$ & 54.4 & 5.2 & 0 & 0 & 40.4 & 0.4 & 75.7 & 24.2 \\
\hline
\end{tabular}




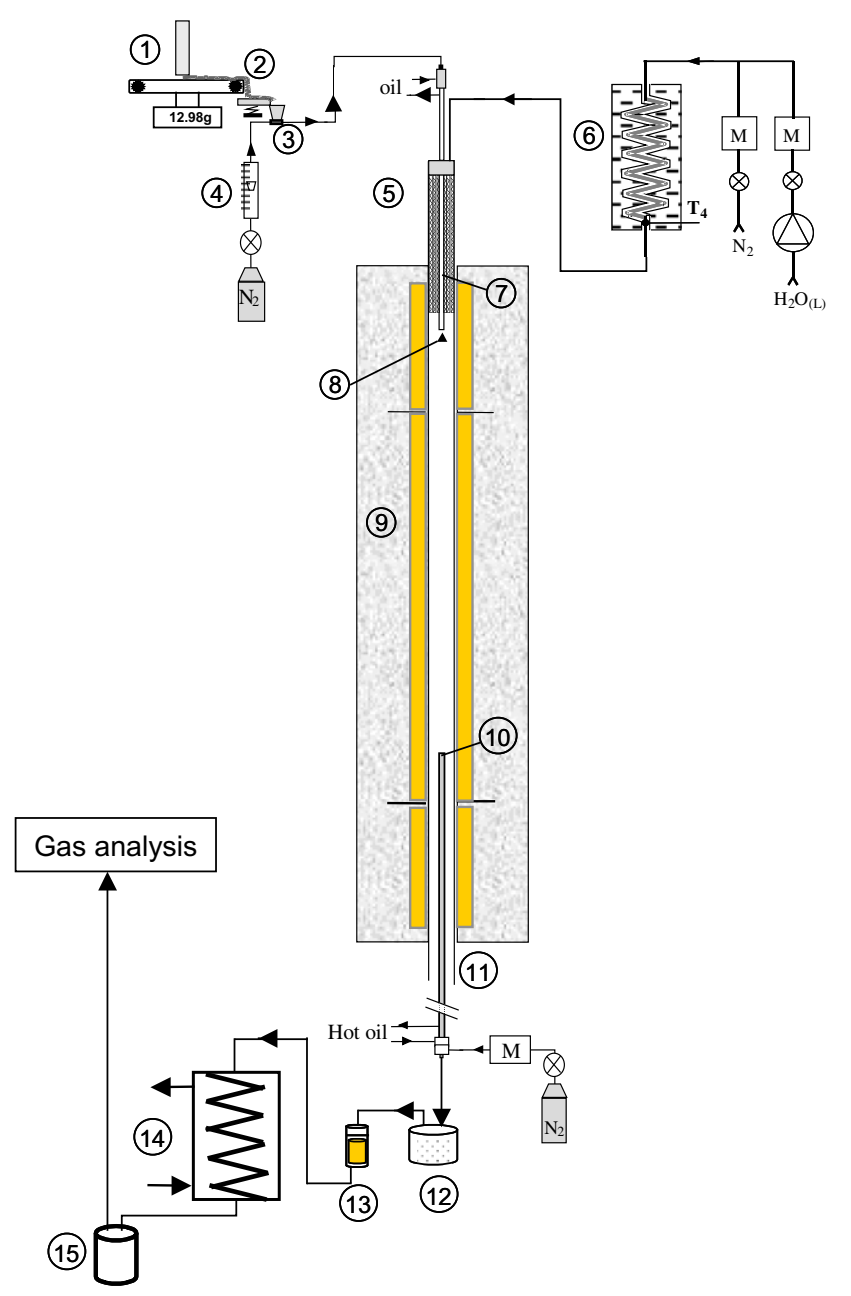

1: gravimetric feeding system; 2 : vibrating channel; 3 : pneumatic ejector; 4: flow meter; 5: electrical preheater; 6: steam generator; 7: water cooled feeding probe; 8: dispersion dome;

9: three zones electrical furnace; 10: water cooled sampling probe; 11: $75 \mathrm{~mm}$ i.d. alumina reactor; 12: hot settling box; 13: hot filter; 14: coolant; 15: condensed water collector;

M: mass flow meter/controller

Fig. 2. Gasification reactor

During experiments, the atmosphere gas and the reactor walls were heated to $1200^{\circ} \mathrm{C}$ or $1400^{\circ} \mathrm{C}$. Measurements of the gas phase temperature inside the reactor indicated temperatures close to those of the reactor walls, with a difference always lower than $30^{\circ} \mathrm{C}$.

\section{Results}

\subsection{Characterization of torrefied woods}

Wood was dried overnight at $105^{\circ} \mathrm{C}$, and then torrefied. After torrefaction at $240{ }^{\circ} \mathrm{C}$ and $260^{\circ} \mathrm{C}$, the observed mass losses were $11.5 \%$ and $21.0 \%$, respectively of the mass of dry wood. The experiments were repeated and the results deviated by less than $1 \%$. These results are in agreement with the literature $[2,8-10]$. But it is interesting to note that the composition of biomass fuels has a significant impact on the amount of solid residue after torrefaction [2].

As illustrated in Fig. 3, the torrefied wood showed darker brown colours than the initial wood, tending towards black after severe

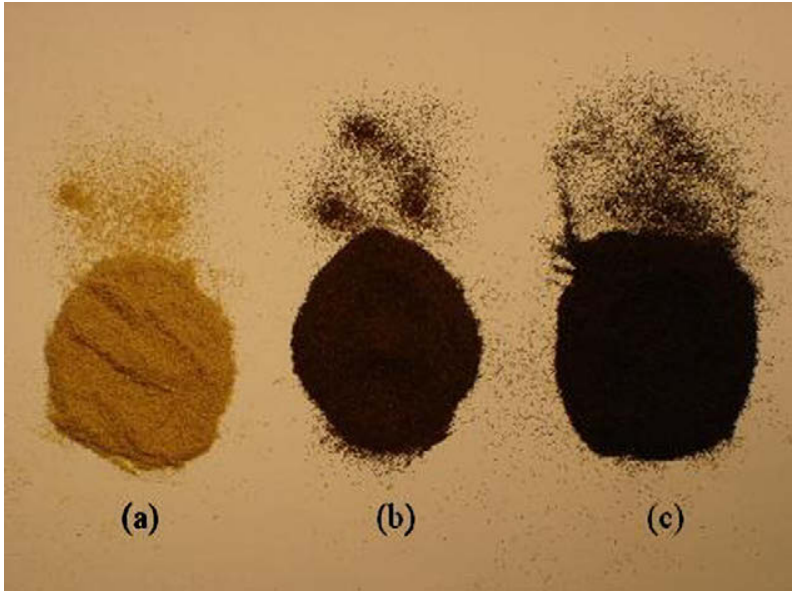

Fig. 3. Photography of particles of beechwood (a), torrefied beechwood at $240{ }^{\circ} \mathrm{C}$ (b) and torrefied beechwood at $260^{\circ} \mathrm{C}$ (c).

torrefaction. After the two treatments, the wood particles - observed with an optical microscope - preserved their external shape aspect.

The volatile matter content decreased from $84.2 \%$ for wood down to $80.6 \%$ and $75.7 \%$ for the torrefied woods (Table 1 ). This is in agreement with the results of Bridgeman et al. who showed that the trend is towards a reduction in volatile matter and an increase in fixed carbon and ash content [2]. From the ultimate analysis also reported in Table 1, it can be seen that the 0 content decreased from $44.4 \%$ for wood down to $42.9 \%$ and $40.4 \%$ for the torrefied woods, which represents a decrease of $3.4 \%$ and $9.0 \%$ after torrefaction at $240{ }^{\circ} \mathrm{C}$ and $260{ }^{\circ} \mathrm{C}$ respectively. In terms of the $\mathrm{O} / \mathrm{C}$ ratio, the value decreased from 0.88 for wood down to 0.83 and 0.74 for the torrefied woods; which is in agreement with the literature $[2,8,9]$.

These results attest that torrefaction is a way to increase the energy density of the wood by removing oxygen. This is confirmed by the LCV of the products that were measured in a IKA C5000 bomb calorimeter: $19532 \mathrm{~kJ} \mathrm{~kg}^{-1}$ and $20742 \mathrm{~kJ} \mathrm{~kg}^{-1}$ for the torrefied wood at $240{ }^{\circ} \mathrm{C}$ and the torrefied wood at $260{ }^{\circ} \mathrm{C}$, respectively, to be compared with $17782 \mathrm{~kJ} \mathrm{~kg}^{-1}$ for the initial wood, i.e. an increase of $17 \%$ (in the case of torrefied wood at $260{ }^{\circ} \mathrm{C}$ ). Prins et al. showed that the energy density increases with torrefaction temperature and found an increase of $20 \%$ at a torrefaction temperature of $280{ }^{\circ} \mathrm{C}$ [8].

\subsection{Gasification experiments and results}

\subsubsection{Gasification experiments and modelling at $1400^{\circ} \mathrm{C}$}

The two torrefied woods - and the initial wood as a reference were gasified at a temperature enabling a nearly complete conversion to $\mathrm{H}_{2}, \mathrm{CO}$ and $\mathrm{CO}_{2}: 1400^{\circ} \mathrm{C}$. This value was retained from previous experiments. The gas volume fractions in the flue gas were converted into yields, on a dry ash free (daf) basis, and reported in Fig. 4. Each experiment was repeated two or three times enabling repeatability error bars to be drawn on the graph. The analysis indicates that the gasification was actually complete: the concentration of $\mathrm{CH}_{4}$ and other hydrocarbons like $\mathrm{C}_{2} \mathrm{H}_{2}$ and $\mathrm{C}_{2} \mathrm{H}_{4}$ were inferior to $30 \mathrm{ppm}$, the detection limit of the analysers. This corresponds to quantities of less than $0.2 \%$ of the dry wood. The two torrefied woods produced more $\mathrm{H}_{2}$ and $\mathrm{CO}$ than the parent wood, respectively $7 \%$ and $20 \%$ more, which was an expected result since their $\mathrm{O}$ content was lower than that of wood. $\mathrm{CO}_{2}$ yields were quite similar for the wood and the torrefied woods. 


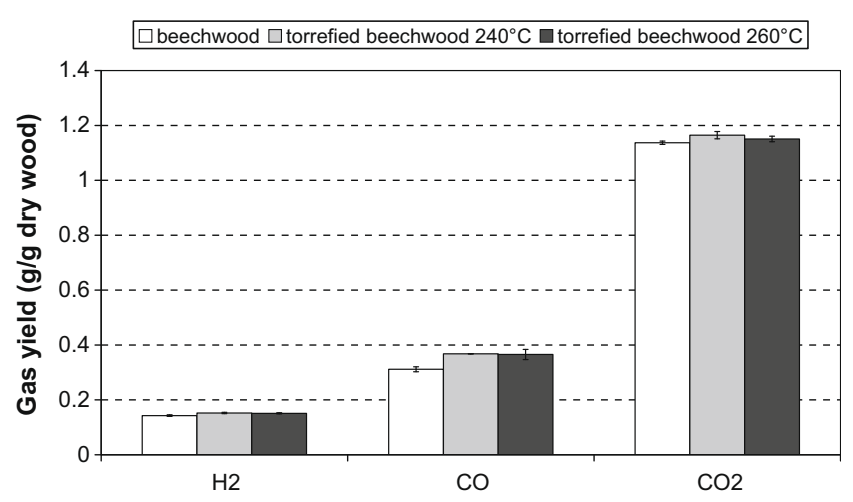

Fig. 4. Gas yields obtained during gasification of beechwood and torrefiedbeechwoods at $1400^{\circ} \mathrm{C}$ under $20 \%$ of steam.

As far as the solid residue is concerned, only grey coloured ash was recovered after gasification, in such small quantities that collecting and weighing them would not have been accurate.

Given the small size of the particles and the high operation temperature, a thermo-dynamical equilibrium type model was selected to describe the previous experiments. The FactSage ${ }^{\circledR}$ software with the "FACT 5.3" data base (4429 species) was used to this purpose. The inputs of the model were:

- the quantities of $\mathrm{C}, \mathrm{H}$ and $\mathrm{O}$ contained in the dried wood as determined from ultimate analysis;

- the quantities of $\mathrm{H}$ and $\mathrm{O}$ contained by steam and of $\mathrm{N}$ in the atmosphere;

- the temperature of gasification;

- the pressure of the reactor (atmospheric).

The results are reported in Fig. 5 together with experimental results. They show that model and experiments are in agreement concerning $\mathrm{H}_{2}$ and $\mathrm{CO}_{2}$ yields. The $\mathrm{CO}$ yields obtained with the model are higher than those obtained during experiments. This model shows that carbon mass balance is not closed - with an error of $8 \%$ - during experiments. This error can be attributed to the sum of uncertainties resulting from ultimate analysis of the woods and of gas sampling and analysis.

As regards $\mathrm{CH}_{4}$ and hydrocarbon amounts produced, the model predicts no $\mathrm{CH}_{4}$ no $\mathrm{C}_{2} \mathrm{H}_{4}$ and no $\mathrm{C}_{2} \mathrm{H}_{2}$. This is in agreement with the results obtained experimentally.

It can be concluded that the thermo-dynamical equilibrium approach can be retained in such conditions to describe the gas yields from woody and torrefied wood biomass.

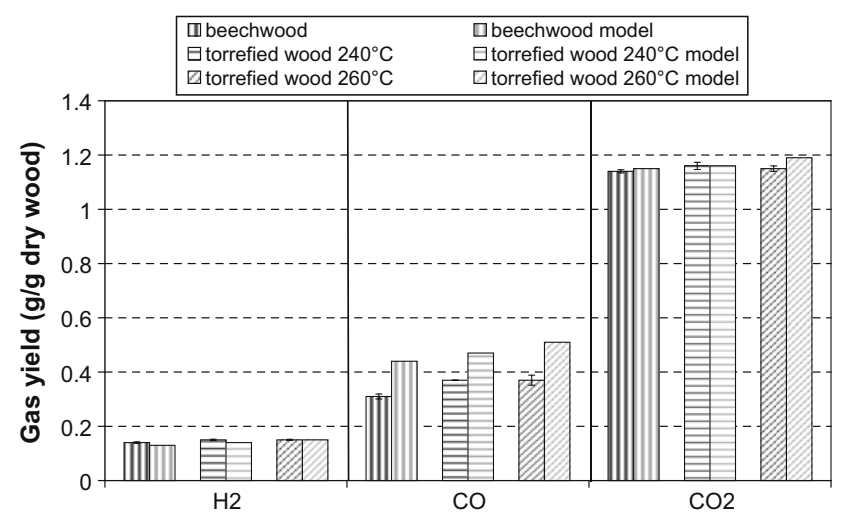

Fig. 5. Experimental gas yields and "model" gas yields for gasification at $1400{ }^{\circ} \mathrm{C}$ of beechwood and torrefied beechwoods.

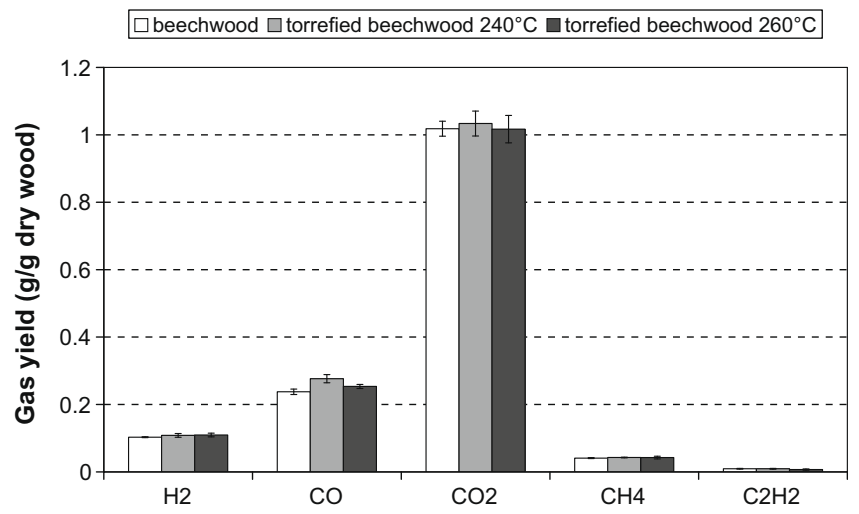

Fig. 6. Gas yields obtained during gasification of beechwood and torrefied beechwoods at $1200{ }^{\circ} \mathrm{C}$ under $20 \%$ of steam.

\subsubsection{Gasification experiments at $1200^{\circ} \mathrm{C}$ - kinetic aspects}

The following section aims at answering a question: does torrefied wood require more severe conditions for gasification to operate? Indeed, the previous experiments of complete gasification did not provide information on this point. The gasification was therefore also operated at a lower temperature, $1200^{\circ} \mathrm{C}$, to compare the gasification progress in the cases of wood and of torrefied woods.

The results reported in Fig. 6 show that gas yields of wood and torrefied woods are quite similar. However, $\mathrm{CO}$ and $\mathrm{H}_{2}$ yields of torrefied woods are slightly higher than those of wood, as was the case with experiments at $1400^{\circ} \mathrm{C}$ where equilibrium was reached. It can be noted that $\mathrm{CO}_{2}, \mathrm{CO}$ and $\mathrm{H}_{2}$ yields are lower at $1200{ }^{\circ} \mathrm{C}$ than at $1400^{\circ} \mathrm{C}$, showing that gasification is not finished at $1200^{\circ} \mathrm{C}$.

During rapid high temperature pyrolysis of thin wood particles, $\mathrm{CH}_{4}$ is produced in quantities of about $6 \%$ of the dry wood [13-15]. $\mathrm{CH}_{4}$ is then cracked and reformed by steam and converted to $\mathrm{CO}$ and $\mathrm{H}_{2}$, but this species is the most thermally stable hydrocarbon species and takes the longest time to reform by steam. However, it can be observed in Fig. 6 that the residual amounts of $\mathrm{CH}_{4}$ are similar after gasification of wood and torrefied woods, which confirms that chemical reaction kinetics in gas phase are quite similar.

As regards the amounts of residual carbon, i.e. carbon that was not gasified into $\mathrm{CO}$ and $\mathrm{H}_{2}$ by steam, the quantities collected were approximately $1.1 \%$ of the initial mass of wood and $4.8 \%$ of the initial mass of torrefied wood. Sampling of solid residue in the entrained flow reactor was not isokinetic. Therefore, these results are not very accurate but clearly show that more char is collected after gasification of torrefied woods. Moreover, proximate analysis performed on all solid residues showed that the char from wood contained $66 \%$ of ash, whereas the chars from torrefied woods contained $26 \%$ of ash. Chars from torrefied woods contained more residual carbon, which confirms that they are less reactive than the char from wood. One could think of using the ash tracer method to calculate the conversion progress of char gasification in the two cases of wood and torrefied wood. Nevertheless, the calculation would not be accurate enough, regarding the very low ash content of the parent wood.

\section{Conclusions}

The gasification for $2 \mathrm{~s}$ at $1400{ }^{\circ} \mathrm{C}$ of a wood and of its product after torrefaction with two levels of severity indicated that the torrefied woods produce approximately the same quantities of $\mathrm{CO}_{2}, 7 \%$ more $\mathrm{H}_{2}$ and $20 \%$ more $\mathrm{CO}$ than the parent wood. In these conditions where thermo-dynamical equilibrium is reached, this 
result is consistent with the increase in the $\mathrm{C}$ and $\mathrm{H}$ content induced by torrefaction.

From gasification experiments performed at a lower temperature, $1200^{\circ} \mathrm{C}$, it can be stated that the kinetics of gasification in gas phase of torrefied wood is comparable to that of the parent wood. However, the chars from torrefied woods are less reactive towards steam than the char from wood.

\section{Acknowledgement}

We wish to thank the Agence Nationale de la Recherche for having funded this project.

\section{References}

[1] Svoboda K, Pohorely M, Hartman M, Martinec J. Pretreatment and feeding o biomass for pulverized entrained flow gasification. Fuel Process Technol 2009;90:629-35.

[2] Bridgeman TG, Jones JM, Shield I, Williams PT. Torrefaction of reed canary grass, wheat straw and willow to enhance solid fuel qualities and combustion properties. Fuel 2007. doi: 10.1016/j.fuel.2007.05.041.

[3] Arias B, Pevida C, Fermoso J, Plaza MG, Rubiera F, Pis JJ. Influence of torrefaction on the grindability and reactivity of woody biomass. Fuel Process Technol 2008;89:169-75.

[4] Xuan Phuong L, Shida S, Saito Y. Effects of heat treatment on brittleness of styrax tonkinensis wood. J Wood Sci 2007;53:181-6.
[5] Repellin V, Guyonnet R. Evaluation of heat treated beech by non destructive testing. In: Proceedings of the first european conference on wood modification, 3-4 April 2003, Gand, Belgium.

[6] Bergman PCA, Boersma AR, Kiel JHA, Prins MJ, Ptasinski KJ, Janssen FJJG. Torrefaction for entrained flow gasification of biomass. In: Van Swaaij WPM, Fjällström T, Helm P, Grassi A, editors. Second world biomass conference, Rome, Italy. ETA-Florence and WIP-Munich; 2004. p. 679-82.

[7] Bergman PCA, Kiel JHA. Torrefaction for biomass upgrading. In: Proceedings of the fourteenth european biomass conference and exhibition, 17-21 October 2005, Paris, France.

[8] Prins MJ, Ptasinski KJ, Janssen FJJG. Torrefaction of wood. Part 2. Analysis of products. J Anal Appl Pyrolysis 2006;77:35-40.

[9] Prins MJ, Ptasinski KJ, Janssen FJJG. More efficient biomass gasification via torrefaction. Energy 2006;31:3458-70.

[10] Prins MJ, Ptasinski KJ, Janssen FJJG. Torrefaction of wood. Part 1. Weight loss kinetics. J Anal Appl Pyrolysis 2006;77:28-34.

[11] Klose W, Wolki M. On the intrinsic reaction rate of biomass char gasification with carbon dioxide and steam. Fuel 2005;84:885-92.

12] Di Blasi C. Combustion and gasification rates of lignocellulosic chars. Prog Energy Combust Sci 2009;36:121-40.

[13] Couhert C. Pyrolyse flash à haute température de la biomasse lignocellulosique et de ses composés-production de gaz de synthèse. PhD thesis, Ecole des Mines de Paris; 2007.

[14] Couhert C, Commandré JM, Salvador S. Is it possible to predict gas yields of any biomass after rapid pyrolysis at high temperature from its composition in cellulose, hemicellulose and lignin? Fuel 2009;88:408-17.

[15] Dupont C. Vapogazéification de la biomasse: contribution à l'étude phénoménologique entre 800 et $1000^{\circ} \mathrm{C}$. PhD thesis, Université Claude Bernard - Lyon I; 2006. 